\title{
Exploring the Relevance of Feminist Leadership in Theological Education of Nigeria
}

\author{
Adesanya İbiyinka Olusola
}

Ekiti Atate University, Ado-Ekiti, Nigeria

\section{Introduction}

In many areas of the world, particularly in Nigeria, the church is growing at a phenomenal rate. It is a common sight to see a minimum of fifty different churches on a street of 4 kilometers long. This may paint a terrible picture but such is the present rate of church proliferation in the country In a statement made by Ogidi, he categorically asserts that, "Nigeria is a country with easily the largest number of

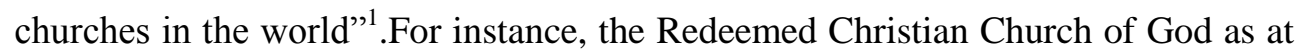
2009 had 22,669 parishes and more had been added because the church usually established parishes during Easter and December Let's Go Fishing Program ${ }^{2}$. Then, it needs be noted that more parishes are being established on daily basis in other denominations like Catholic, Anglican, Methodist, are being and new religious movements continue to spring up each passing day.. Although this growth has some advantages for the nation, society and religious bodies as a whole. The merits include, rapid evangelization, developments of new leadership, provision of checks and balances to orthodox churches, specialization in ministries and the likes. But at the same time, there are many attendant problems like, wrong doctrines, misinterpretation of scriptures and teachings called sound doctrine that is based solely on abstract proposition known as theology or denomination doctrinal statements that make women's emancipation impossible, unhealthy competition for converts and so on ${ }^{3}$. With this situation, there is need for mature, well-trained

\footnotetext{
${ }^{1}$ Ogidi, R.(1997) "Worries over Failure of Religion as Moral Anchor”, The Guardian, March,28. p.11.

2 . Adesanya, I.O. (2011), Environmental Effects of Proliferation of Churches: The Redeemed Christian Church of God as a case study, International journal of Humanities and social sciences, 1, (15), p.177.

3 .Bankole, Tokunbo (2007), "Proliferation of Churches in Ekitiland, 1979-2004", an unpublished M. A Dissertation submitted to the Department of Religious Studies, University of do- Ekiti, p.40-45.
} 
leaders particularly the feminist in the area of women studies, which would anchor mentoring, assessment and impact people in their ministries.

However, over the past century, the church seems to shy away to the inclusion of feminist leaders in theological education. In Nigeria, most of the Christian churches have theological colleges such as Trinity Theological college Umuahia, School of Ministry of Mountain of fire and Miracles ministries Lagos, Methodist Theological Institute Umuahia, Emmanuel college of theology Ibadan, SS Peter and Paul Major seminary Ibadan, Missionary seminary of St Paul Abuja among others. There, the priest or ministers of the gospel are being trained and prepared for ministerial responsibilities. Most of the theological schools are affiliated with Department of Religious studies in most Nigerian University. Their programs are only limited to theological courses such as church dogma, systematic theology and practical theology. ${ }^{4}$ This to a large extent has a lot of implications considering the oppression that women are suffering in our patriarchal culture and through some church laws that discriminate against women's involvement in church programs. Also there are theological or faith statements that are used to justify basic human problems and certain people, waging war against other people, keeping silence in the face of injustice, such a theologizing does not bear witness to the purpose and plan of God for women.

The burden of this paper therefore is to adduce evidence, as far as it is possible for the need to explore the leadership relevance of feminist in theological education. Be that as it may, the paper will take a look at the basic contributions of feminist in biblical studies. But then, there is need for further clarifications of what we mean by feminist leadership and theological education. This will be considered below.

\section{Conceptual Framework}

In order to understand the relevance of feminist leadership in theological education, it is important to understand the following concepts:

*Feminism

*Feminist Leadership

*Theology

\footnotetext{
${ }^{4}$ Nmah, P.E. (2013) Theological Education and character Formation in Nigerian Christianity: A reflection, African Review, 7(1), pp.34-46.
} 


\section{*Theological Education}

Feminism according to Webster's New Universal unabridged Dictionary is the doctrine advocating social and political rights of women equal to those of men or an organized movement for the attainment of such rights for women. Put differently, feminism is grounded on the belief that women are oppressed or disadvantaged by comparison with men and that their oppression is in some way illegitimate or unjustified. ${ }^{5}$ Feminism is also a perspective or world view two long terms goals- the achievement of women's equality, dignity and freedom of choice through women's power to control their own lives and bodies within and outside the home. This does not refer to hope of domination over others, but as a source of internal strength, the rights to determine one's choices and ability to influence social processes and the directions of change ${ }^{6}$. In the same vein, feminism refers to adopting a frame of reference in which women's different and differing ideas, experiences, needs and interests are taken as valid in their own rights and form the basis of teaching and learning ${ }^{7}$.

Three levels of feminism may be identified:

1. Feminism as an academic method- this signifies a definite transition from androcentric to androgynous models of humanity and language for the Supreme Being.

2. Feminism as a value system and social vision- viewing sexism and patriarchy as immoral and proposing alternative social arrangements that foster equity, Thus agitations for women leadership in the society seeking to make the leadership cadre in society open to both male and female

3. Feminism of insider's discourse- this is an attempt to move from the prescriptive to the descriptive, so that women' lives become the textbook for roles expected of them in the society. ${ }^{8}$

\footnotetext{
${ }^{5}$ Concise Routledge Encyclopaedia of Philosophy, (2000) London: Routledge.p.275.

${ }^{6}$ C. Bunch, (1979). "Some Definitions of Feminism", International Workshop on Feminist ideology. Bangkok, Documents from the Network for women studies in Nigeria.

7 . G. Bowles and R.D. Klein,(1983) "Introduction: Theories of women's studies and the autonomyIntegration Debate" in G. Bowles, R.D. Klein, eds., Theories of women's studies, London, Routledge, p.45.

${ }^{8}$ Oyeronke Olademo (2010) “ Doing Theology in Africa from a Feminist Perspective, a text of Paper for NABIS Western Conference held at the University of Ibadan in honor of Late Dr Akintunde Dorcas, p.5.
} 
Hence, as rightly observed by Tracy Barton, leadership from a feminist standpoint is informed by the power of feminist lens which enables the feminist leader to identify injustices and oppression and inspires her to facilitate the development of more inclusive holistic communities. He further notes that, feminist leaders are motivated by fairness, injustice and equity and strive to keep issues of gender, race social class, sexual orientation, and ability at the forefront ${ }^{9}$. Dawn Ontario in her own view notes that, feminist leadership is women and women's organizations sharing power, authority and decision making in our common pursuit of social, legal, political, economic and cultural equality ${ }^{10}$.

Flora Crater provides an interesting definition. She says, leadership as a function of growth, is also then, the process of building confidence, not only so that others will attempt leadership themselves... it is especially a form of stewardship. ${ }^{11}$ Also, Admira Toolkit says, feminist leadership is oriented to different arrangement of the human order, re-distribution of power and re-distribution of responsibilities, fighting societal inequalities, changing economic and social structures, beginning in the transformation of psychic structures, bridging personal freedom with collective freedom, aiming at cooperation instead of competition ${ }^{12}$. Put succinctly, feminist leadership would be something like this:
women with a feminist perspective and vision of social justice, individually and collectively transforming themselves to use their power, resources and skills in non- oppressive, inclusive structures and process to mobilize others- especially other women - around a shared agenda, of social, cultural, economic and political transformation of equality and the realization of human rights for $\mathrm{all}^{13}$.

\footnotetext{
${ }^{9}$ Tracy Barton, (2006) "Feminist Leadership: Building Nurturing Academic Communities, online Journal, Vol 21, Fall.

${ }^{10}$ Dawn Ontario,(2008) http:// dawn.thot.net/feminism html. "The Feminist principle of Leadership."

${ }^{11}$ Flora Crater, (no date), Leadership Growth and spirit", in Quest, A feminist Quarterly, 11(4), pp. 60-66.

${ }^{12}$ Admira Toolkit, Section 8, "Management and Leadership", Feminist Leadership available at http://www. Zenska-mreza.hr/prirucnik. Len/en-read

${ }^{13}$ Srilatha Batliwala(2008), "Feminist Leadership for social Transformation". This publication was commissioned by CREA as a resource for a meeting, "Building Feminist Leadership- Looking Back, Looking Forward", Cape Town, South Africa, p.29.
} 
Meanwhile, theology is an expression derived from two Greek words- theos and logos, meaning God and discourse respectively. In its most general sense, theology applied to scientific investigations of real or supposed sacred persons, things or relations. The use of the term theology is therefore acceptable once it has to with the sacred. The different forms of theology include, natural, exegetical, historical, systematic and practical theologies ${ }^{14}$ Also, some scholars consider theology as a form of thinking that seeks to explain or systematize beliefs of a people about their god. Also theology is noted to be an intellectual quest that aims at attaining the highest possible degree of intelligibility, clarity and consistency in its attempt to investigate, explain and systematize the understanding of the religion of people ${ }^{15}$.

Therefore theological education has been defined as the task to motivate, equip and enable the people of God to develop their gifts and offer their lives in meaningful service. It has been affirmed as theological in the term that it involves people in commitment and ministry, a commitment to the study of God in the sense of God's revelation in the life of Jesus Christ and God's continuous working through the Holy Spirit. ${ }^{16}$

Edgar. B, classified different approaches to theological education such as, "Athens (which stresses the role of the academy in transforming the life of individual). "Berlin (which represents a University mode which focuses on the need to, educate competent professionals to strengthen the life of the church), and "Geneva" (which represents an explicitly confessional seminary approach to training ${ }^{17}$. However, Kelsey, D.H. examines theological education using an historical typology, referring to Athens and Berlin representing two different approaches ${ }^{18}$.

Relating the two concepts, (feminist and theological education) it is sufficed to say that they seem to have something in common. Theological education is very interesting because it focus on learning historical facts and this is done by analyzing and reconstructing history, rather than accepting biblical tradition testimonial without suspicion. It also seeks to re-examine the scripture and the written tradition by discovering their androcentric elements. Feminist leaders or

\footnotetext{
${ }^{14}$ www.wrs.edu-27-2-12.

15 Oyeronke Olademo, op.cit, p.2.

${ }^{16}$ Letty, M. Russel and Shannon Clarkson (eds),(1996) " Theological Education in Dictionary of Feminist Theologies, Westminister, Knox Press. pp. 282-283.

${ }^{17}$ Edgar, B. (2012) Brian's Public theology, New York, Orbis p.34.

${ }^{18}$ Kelsey, D. H. (1993), Between Athens and Berlins: the Theological debate, Grand Rapid: Eerdmans, pp20-23.
} 
theologians on the other hand believe that theology has not taken into account the experiences of both men and women. So, feminist leader or theologians have undertaken the task of rethinking traditional theological notions from the perspectives of women's experiences. ${ }^{19}$ Fortunately that seems to be one of the objectives of theological education as explained above. Theological education is to analyze and reconstruct history particularly, when it has to do with issues about women that are negative in the Bible. This seems not to be so as our theological education are male-dominated. The task of re-working oppressive elements in biblical traditions is not undertaken by male who are mainly teachers of our seminaries and theological schools.

In this paper therefore, "Berlin and Athens" model stated above will form the basis of this work. The two models in a way does not give room for dogmatism as it is the case in most Nigerian theological schools The pertinent issue in this paper is that feminist leaders should be involved in theological education because their presence could serve as a platform to explore the gospel from a feminist perspective.

\section{Reasons for concern}

First, the memory begins with the Old Testament story of Adam and Eve; the Bible teaches that women brought sin and death to the world. ${ }^{20}$ In church traditions, sin has been interpreted not only individualistically but also associated with sex and women. Women and other groups often begin with an attitude toward the accepted roles of their culture which may be characterized as the happy slaves. Here a woman sees herself as fulfilled in the accepted roles of mother, secretary, servant and sex symbol. A forthright rejection of such misogyny, including the interpretation of the Adam and Eve story which from this perspective can be seen in many feminist writers, for instance, Mary Daly writes

In the mentality of the fathers woman and sexuality were identified. Their horror of sex was also a horror of

\footnotetext{
${ }^{19}$ Feminist leaders in this category are many but two will be mentioned here. Elizabeth Schussler Florenza, who encourages readers of scripture to look for the presence of women in the margins and around the edges of the biblical text. Judith Plaskow, "Standing Again at Sinai", calls for a reconceptualization of notions of God, Torah and Israel that are inclusive of women.

${ }^{20}$ Elizabeth Cady Stanton. (2001), Introduction to the woman's Bible in "Susan M, Shaw and Janet Lee(eds), Women's Voices, Feminist visions New York McGraw Hill, p.245.
} 
woman. There is no evidence that they realized the projected mechanisms involved in this misogynistic attitude. In fact, male quilt feelings over sex and hyper- susceptibility to sexual stimulation and suggestion were transformed to the other quilt $\operatorname{sex}^{21}$.

Women were generally regarded as inferior to men and believed not to be different from the male counterpart physically and intellectually. This believes characterized most culture in Nigerian society. For example the Yoruba woman of south western culture of Nigeria is not traditionally portrayed as independent, decisive or active in "masculine" areas but subordinate while her major role is in household activities. ${ }^{22}$ She is not regarded as valuable or preferred as the male who is regarded as "Arole" (one who will keep the family name in successive generations). Yoruba culture also conceives the woman as inferior, cowardly and as a betrayer and as traitor hence the Ifa corpus states, "Obinrin l' odale ati eke, e ma finu han obinrin", meaning women are traitors and betrayers, don't open mind to women ${ }^{23}$.

The second cause for concern is the aspect of incarnation called scandal of particularity" by G. Kittel ${ }^{24}$. According to him, the scandal is not seen by most women in Jesus Jewishness, but most importantly in his maleness. ${ }^{25}$ Although Christian women can see in Jesus a unique revelation of true personhood, one who helped both men and women to understand their own personhood. ${ }^{26}$ The life of Jesus displays characteristics of love, compassion and caring often considered to be cultural characteristics of women. In his own life he was a 'feminist' in the sense that he considered men and women equal, equal in their need to be helped and equal in their need to be pointed toward the new future of God's kingdom ( Luke 10 : 38-42, John 4: 7- 30). However, the most important affirmation that the feminist are concern about is that they want women to be accepted as subjects and persons, within whom biological differentiation is a secondary aspect It is however clear that women prefer the feminist option in scriptural interpretation and discourse.

\footnotetext{
${ }^{21}$ Mary Daly, (1973) Church and the Second sex, c.f., Rosemary Ruether, Is Christianity Misogynist,pp. 95-113.

${ }^{22}$. N. A Fadipe,(1970). The Sociology of the Yorubas, Ibadan, University press, pp.78.

23 . Olu Akintunde,(1999) "The Plight of Widows" in Essays in Honor of Prof Adelugba at 60, ed. Egbe Ifie, Ibadab D Publishing House, pp.45-58.

${ }^{24}$ G. Kittel in Letty M. Russel,(1974) Human Liberation in a Feminist Perspectives- A Theology, Philadelphia, The Westminister Press, pp. 136-138.

${ }^{25}$ G.Kittel.

${ }^{26}$ Swidler, M.(1971) 'Jesus was a Feminist, Catholic World,p.177.
} 
Unlike in Judaism and Christianity and Islam in which God's worship is male led and male dominated, , J. O Awolalu observes that in African Traditional Religion, both male and female elements operate together. ${ }^{27}$ There are places where the Supreme Being is conceived as male and there are other places God is a female. He also observed that the Yoruba language does not distinguish between genders in their use of pronouns ${ }^{28}$. The fact is that in Africa God can be conceived as both Father and Mother and as male and female. For example among the Yoruba, the expression "I know God and I love Him" will be translated as "Mo mo Olorun, mo si feran Re". The word "Re stands for both "him and her". In view of this it is always difficult to know the gender used for the Supreme Being in written literature. $^{29}$

The third related problem is the language of servant hood or subordination being used for women. Most women and the modern society do not like the idea of servant hood because they see it as an expression of their own powerlessness. Too long they have been the servants of men. Also, women's groups' organizations have had to settle for the supportive and listening role in matters of theological, social research and leadership in the church. ${ }^{30}$ Social structures have dictated the subordinate roles which women were allowed to play, and the church male hierarchies have claimed divine sanction for these roles. So debased is the usage that men and women alike often think of it only as referring to a 'Band Aid' type's assistance. What we are saying in essence is that, now it is time for women to play the listening role of Mary, listening to Jesus and acting out the gospel of freedom, rather than remaining in the church kitchen with Martha (Luke 10:38-42).

In Africa, most of "the established" churches still regard the role of woman as secondary in religious worship. When they perform any function at all, such functions are mainly secondary nature The traditional practice of keeping women at the background still characterizes the historical Christian denominations in Nigeria such as Roman Catholic Church, the Anglican, the Methodists and the Baptists. Until recently, women ministers are few especially in Methodist church where we now have only seven priests. Internationally, women ordination where it exists is merely professed as secondary and not on the same status as men except in

\footnotetext{
${ }^{27}$ J. Awolalu,(1976) “Women from the Perspective of Religion” Orita: Ibadan Journal of Religious, vol. x, No 2, pp. 93.

${ }^{28}$ J.O. Awolalu.

${ }^{29}$ J.O. Awolalu, pp. 93- 104 ..

${ }^{30}$ Swidler, M. op.cit.
} 
the Episcopal Church of U.S.A where women have ordained priests and consecrated bishops. However, in contrast to, the Independent African Churches give a place of honor to women. They are integrated in the decision making processes and exercise certain degree of power and authority. A large number of women have become charismatic leaders of their churches. For example, Lady Archbishop Dr. D.S Olaniyi of Agbala Daniel Church, Ibadan, Captain Abiodun Akinsoewon,Prophetess Yemi Adesida a.ka. Omo-Oba Jesu of Possibility church of the Lord, Bishop Dr. Elizabeth Idahosa of Church of God Mission Benin City to mention but a few. Women are seen as spiritually important as men, many of whom hold leadership position. It is also necessary to note that despite the encouragement given to women to serve in various capacities especially in the priesthood of the church, that power of decision making are still in the hands of men.

My understanding of the above is that, for Christian women in this situation, doing theology is not just an added luxury after developing expertise in other discipline. Doing theology is itself an act of freedom. It is a critical means of searching out the right questions about the Bible and ecclesial tradition, about God and faith. Instead of accepting a certain text delivered from the father's, serious questions must be raised in order to try to discern what it means to be real life children of God.

The fourth problem, which has become very prominent in recent time, is that of theological methods and processes that are full of stereotypes. In other words, there are standardized mental images that are based on prejudicial attitudes or lack of critical judgment. An example of such beliefs would be stereotypes of women as weak, passive, irrational and men as strong, active and rational. Stereotypes of such as these are used to support claims - in theology and in the church as well - that women are inferior to men and thus legitimatized relations of male domination and female subordination. ${ }^{31}$

Lastly, theological education is still under the umbrella or the influence of some conservative clerical movement. African women who are in theological education are well aware of the reluctance on the part of some churches (Anglican communion, Methodist, Roman Catholic to mention but few) to send some women for theological training. For instance Isabel Apawo showed in her paper, that she was part of the Theological institutions in Indonesia where it was highlighted that

\footnotetext{
31. Letty M.Russell,(1971) Human Liberation in a Feminist Perspectives- A Theology, Philadelphia,pp .31-34.
} 
there is male domination of the theological curriculum, staff and student members and something must be done to redress the situation. She further observed that, most theological institutions in Africa follow a curriculum that reject the Old European list of classical religion and theological courses Also, most of those courses are taught by male professors and unfortunately very often they end up as a course exclusively for a few women student. ${ }^{32}$

These five causes for concern - sin and death associated with women scandal of particularity, servant hood, stereotypes and domination of ministries by men are integrally related to one another and together constitute a single 'interlocking global crisis for women.' the question is have feminist leadership anything special or relevant to offer theological education. The answer is in the affirmative, yes. This will be considered below.

\section{Relevance of Feminist Leadership}

Although, some feminist believes in the reinterpretation and reconstruction of scriptures and choose to work within existing denominations, others prefer to create their own empowering religious texts and organizations. However, as a matter of emphasis the African feminist particularly in Nigerian did not see possibility in the reconstruction of biblical text as this cannot change the patriarchal teachings and ideas in our society. Rather, it is their priorities to identify women in theological institutions and work towards creating theology that seeks the liberation of women from oppression and discrimination. The Circle of Concerned African Women Theologians is one of such groups comprising scholars and members of churches who target the gospel from African perspectives. The mission of the circle is to undertake research writing and publishing on African issues from women's perspective. The vision of the CIRCLE is to empower African women to contribute their critical thinking and analysis to advance current knowledge. ${ }^{33}$

Then, if the above is the case, it could be said that theological education can be enriched if feminist leadership in Nigeria is employed. Feminist leadership means the ability to influence agendas even without the formal power or authority to do so.

\footnotetext{
${ }^{32}$ Isabel Apawo Phiri, "Major Challenges for African Women Theologians in Theological Education, an unpublished paper, p.10.

33 Rebecca S. Chopp,(1995) Saving Work: Feminist practices of Theological Education, Louisville, Kentukky, Westminister press,p.8.
} 
They can make contributions to the unfinished dimension of theology. As noted by Oyeronke Olademo, feminism in the contemporary church in Africa provides interpretations for sections of the Bible that utilizes female symbolism for God, for example Isaiah 49: 15, Paul's list of helpers in Roman's chapter 16 and the extensive work of late Dr .Mrs. Dorcas Akintunde on the role of women in the ministry of Jesus as recorded by Luke's gospel among many other feminists Certain salient principles have been unearth by this innovative engagement of feminism with scriptural interpretations including the notion of reading between lines, which sometimes produces more information than what it is written ${ }^{34}$. In addition, it has been observed that feminist engagement with the gospel in Africa brings to fore the reality that text operates as a tool for cultural replacement in the process of interpretation ${ }^{35}$. Though it was clear enough that much ground still remains to be covered, but it is now clear that women are prominent and their voices are heard and are taken seriously.

Feminist leaders will add to the understanding of the Christian growth, not to replace the other insights that have been contributed to in the past. This is very important to a Christian church that has been dominated by white western male perspectives of God. Women would add their small piece of experience about the way God is known to them, so that theology becomes more wholistic and comprehensive.

Feminist leadership is grounded in mutuality and equality not in hierarchy. They would promote the teaching of gender issues in the theological curriculum. This means making gender as a concept in theological analysis. A gender approach to theology refers to exposing the injustices that exist in the church, culture and the Bible in the relationship between men and women. It acknowledges that human beings construct culture, therefore cultural practices in the Bible should not be confused with the will of God.

Feminist leadership is a group centered not authority- figure centered. They will work with theological institutions to promote the employment of African women as lecturers of theological disciplines in permanent positions.

Feminist leaders are generally sensitive to people's needs and to emerging situation. They will play advocacy role for the provision of good accommodation that is

\footnotetext{
${ }^{34}$ Oyeronke Olademo, op.cit. p.8. Statement made by M. Dube, see www. Cgu.edu- 10/2/12.

${ }^{35}$ Ibid.
} 
conducive to the process of learning for female theological students. They will also play advocacy role by connecting African women with funding agencies, who are interested in promoting the theological education of African women. Also, there presence would afford them the opportunity of encouraging many women to enroll in theological schools. For instance, Mercy Amba Oduyoye has channeled large amounts of money into theological training in Africa in the past decade and now. This has borne fruit in greatly increased in number of active women theologians. Within the ecumenical Association of third World Theologians, the Circle of concerned African women theologians was formed in 1989 in Ghana For example, St Theresa Okure of Nigeria is one of the most notable Biblical scholars. A significant number have equally joined the list, women like Oyeronke Olademoi, R. Modupe Owanikin, Rosemary Edet, Chioma. These women are promoting interpretations of the Old Testament in which equality and mutuality are stressed as biblical ideals. ${ }^{36}$

Lastly feminist leadership is visionary. It aims at empowerment and liberation, not only for the feminist themselves but also for others knowing what is it like to be oppressed, exploited and discriminated. Feminist women generally feel deeply for those who are in such a situation and would work so that no one is in such situation any longer. Hence they will encourage more production of theological literature on gender for the academic use of theological institutions. This in a way will be done in such a way to enhance total human developments. The challenge of feminist leaders is to enable members to be equipped as leaders in their own right, hence the possibility is there that they will clamor for the increase in the way God is known to all, so that theology become more understandable.

\section{Conclusion}

There is a great need for more feminist leaders in our contemporary society and theological schools, who will throw more light to issues affecting women. Their motivation will be thoroughly Christian- a vision of the God who cares about justice, compassion, honesty freedom in society, and a vision of humanity. It would be God and love for their fellow women. They will make no attempt to conceal the truth, and all the time, their target will be the shaping of public opinion about women.

\footnotetext{
${ }^{36}$ Feminist Theological Pedagogy for Ministerial formation, (Limatula LungKumer), CTC Bulletin.
} 
Addressing the need for a balanced theological education of all people, Isabel Apawo Phiri had written:

If indeed the church acknowledges that God gives gifts to both men and women for the common good of the church, then it needs to transform itself to support theological education of both men and women. This requires the realization that according to the signs of our times, theological education should no longer be seen as training of soldiers of Christ to wade off heresy, but servants of Christ willing to build a community of men and women ${ }^{37}$.

A Loades concluded that feminist theologians needs to position itself as it were, within the open space, of empty tomb and the open road to Galilee to experience and proclaim divine and life enhancing power ${ }^{38}$.

When the above ideas begin to trickle down into the minds of ordinary in our churches, the cry for feminist leadership in theological education may last. Therefore, for the Nigerian church to be strong, it is recommended that feminist theologians must be a necessary part of its mission. This is because; it is the best way to prepare natural leaders for the church, which will help women to see her place in God's redemptive plan.

\section{References and Notes:}

Adesanya, I.O. (2011), Environmental Effects of Proliferation of Churches: The Redeemed Christian of God as a case study. International Journal of Humanities and Social Sciences. 1 (15), U.S .A.

Olu Akintunde, (1999) "The Plight of Widows" in Essays in Honor of Prof Adelugba at 60, ed. Egbe Ifie, Ibadan, Publishing House.

Awolalu, J. (1976) "Women from the Perspective of Religion" Orita: Ibadan Journal of Religious Studies, vol. x, No 2.

.Bankole Tokunbo. (2007), "Proliferation of Churches in Ekitiland, 1979-2004", an unpublished Dissertation submitted to the Department of Religious Studies, University of Ado- Ekiti.

\footnotetext{
37 . Isabal Apawo Phiri, op.cit., p. 12.

${ }^{38}$ A. Loades, Feminist (1994) Theology in the section of a new direction in Christian studies: A Reader, London.
} 
Barton, Tracy "Feminist Leadership: Building Nurturing Academic Communities", Online Journal, Vol. 21, fall, 2006.

Bunch, C (1979). "Some Definitions of Feminism”, International Workshop on Feminist ideology. Bangkok, Documents from the Network for women studies in Nigeria.

Bowles, G and R.D. Klein,(1983) "Introduction: Theories of women's studies and the autonomy- Integration Debate” in G. Bowles, R.D. Klein, eds., Theories of women's studies, London, Routledge,

Batliwala Srilatha (2008), "Feminist Leadership for social Transformation”. This publication was commissioned by CREA as a resource for a meeting, "Building Feminist Leadership- Looking Back, Looking Forward", Cape Town, South Africa.

Crater, Flora (no date), Leadership Growth and spirit”, in Quest, A feminist Quarterly, 11(4)

Rebecca S. Chopp ,(1995) Saving Work: Feminist practices of Theological Education, Louisville, Kentukky, Westminister press

Dawn Ontario, (2008) http:// dawn.thot.net/feminism html. "The Feminist principle of Leadership"

Daly Mary, (1973) Church and the Second sex, c.f., Rosemary Ruether, Is Christianity Misogynist

Edgar, B. (2012) Brian's Public theology, New York, Orbis .

Fadipe, N .A (1970). The Sociology of the Yorubas, Ibadan, University press.

Kelsey, D. H. (1993), Between Athens and Berlins: the Theological debate, Grand Rapid: Eerdmans, .

Loades, A Feminist (1994) Theology in the section of a new direction in Christian studies: A Reader, London.

Nmah, P.E. (2013) Theological Education and character Formation in Nigerian Christianity: A reflection, African Review, 7(1).

Ogidi, R. (1997) "Worries over Failure of Religion as Moral Anchor", the Guardian, March, 28.

Oyeronke Olademo (2010) “ Doing Theology in Africa from a Feminist Perspective, a text of Paper for NABIS Western Conference held at the University of Ibadan in honor of Late Dr Akintunde Dorcas.

Phiri Isabel Apawo, "Major Challenges for African Women Theologians in Theological Education, an unpublished paper.

Russell, Letty, M (1971) Human Liberation in a Feminist Perspectives- A Theology, Philadelphia.

Stanton Elizabeth Cady (2001), Introduction to the woman's Bible in "Susan M, Shaw and Janet Lee (eds), Women's Voices, Feminist visions New York McGraw Hill,

Swidler, M. (1971) 'Jesus was a Feminist, Catholic World. 


\title{
Summary
}

\section{Exploring the Relevance of Feminist Leadership in Theological Education of Nigeria}

\author{
Adesanya Ibiyinka Olusola \\ Ekiti Atate University, Ado-Ekiti, Nigeria
}

Feminist leadership is very important in theological education as it would seek to deconstruct stereotypical assumptions about women and gender in Christian theological traditions. Unfortunately, most of the theological schools in Nigeria do not have feminist as leaders. Five reasons why feminist leadership are needed in theological schools have been identified as, the bible teaching that women brought sin and death to the world, servant hood notion of women, scandal of particularity, male domination of ministries and theological methods and process that are full of stereotypes. All this does not provide women a unique opportunity to discover and develop their potential in the church and society. Also, women's relevance and contributions can be hampered if not allowed to put in their optimum. To avoid this, the researcher suggests that theological education should not discriminate against any gender, but should work to bring about gender justice by involving the feminist leaders in theological education in Nigeria. It is hoped that by pursuing these steps, theological education in Nigeria would be preparing the way to sustainable development of the mission of Christ on earth.

Keywords: feminist, leadership, women, theology, bible. 